\title{
FEBRE REUMÁTICA E SUSPEITA DE COVID-19
}

DOI: 10.47224/rm.v5i10.146

Isabella Menezes de Resende Amador ${ }^{1}$

Andressa Medeiros Maciel ${ }^{1}$

Anna Giullia Costa Bruci ${ }^{1}$

Isabela Mansur Rios Moreira'

Nelson Donizete Ferreira Júnior ${ }^{2}$

Fernanda Felipe Cruvinel ${ }^{2}$

Jennyffer de Lima Andrade ${ }^{2}$

${ }^{1}$ Discentes - Centro Universitário IMEPAC Araguari

${ }^{2}$ Orientadores - Santa Casa de Misericórdia de Araguari

e-mail de contato: isamramador@gmail.com

\section{DESCRIÇÃO DO CASO}

Paciente do sexo masculino, 12 anos, natural e procedente de Araguari, Minas Gerais, deu entrada em pronto atendimento de um hospital secundário acompanhado pela mãe e com queixa de dor no joelho esquerdo há 2 dias. O paciente possui histórico de uso de Salbutamol para alívio de crises de dispneia, este, administrado sem prescrição médica, portanto, não soube referir posologia e não possui diagnóstico prévio de doença respiratória. Segundo informações coletadas com a mãe, o cartão vacinal está atualizado e não possui nenhuma outra comorbidade.

Ao exame físico, o paciente está em regular estado geral, fácies de dor, consciente e orientado em tempo e espaço, foi constatado obesidade infantil (IMC acima do percentil 99), artralgia de genicular esquerdo associado a edema local. Este quadro foi conduzido com a prescrição de anti-inflamatório não esteroidal (AINE) diclofenaco $500 \mathrm{mg}$ via oral de $8 \mathrm{em} 8$ horas, o qual evoluiu para melhora da dor por um tempo e, posteriormente, migração da dor para o genicular direito, também associada a edema, além disso, houve evolução com dispneia, taquipneia e hipossaturação.

Devido ao atual momento de pandemia por infecção de COVID-19, após sinais e sintomas respiratórios, foi prescrito isolamento imediato, suporte clínico de paciente e PCR de swab nasofaríngeo para pesquisa de COVID-19. A radiografia de tórax evidenciou cardiomegalia, tomografia de tórax com imagem pulmonar em "vidro fosco" e derrame pleural bilateral, desta forma, solicitou-se, ainda, ecocardiograma transtorácico, com o fito de realizar diagnóstico diferencial, o qual evidenciou hipertrofia excêntrica de ventrículo esquerdo, insuficiência mitral acentuada, aparentemente causada por acometimento reumático, e insuficiência tricúspide de grau leve. Logo, iniciou-se antibioticoterapia, corticoide, oxigênio e diurético. 
Hipóteses diagnósticas: febre reumática; valvopatia; asma; infecção por novo coronavírus; doença de Kawasaki.

O PCR do swab de nasofaringe testou negativo para COVID-19. Após conduta, paciente evoluiu com melhora dos sintomas e recebeu alta hospitalar com solicitação de ASLO, encaminhamento para ambulatório de cardiologia e, seguindo os protocolos para febre reumática, foi prescrito Amoxicilina com Clavulanato 500 +125mg de $8 / 8$ horas e Furosemida 40 mg (1 comprimido pela manhã) para uso realizado em domicílio.

\section{DETERMINANTES SOCIAIS}

1. Baixa renda familiar.

2. Baixa escolaridade dos pais.

3. Pouco acesso à informação e à saúde.

4. Superlotação de serviços de saúde pública.

5. Alimentação desequilibrada.

6. Automedicação.

\section{LISTA DE PROBLEMAS}

1. Febre com acometimento de grandes articulações.

2. Valvopatia.

3. Asma.

4. Infecção por novo coronavírus.

5. Doença de Kawasaki.

\section{PLANO DE CUIDADOS INDIVIDUAL/FAMILIAR}

A febre reumática é uma doença multissistêmica secundária a uma infecção prévia por estreptococo beta-hemolítico do grupo A tratada inadequadamente, a qual desencadeia uma reação autoimune celular com acometimento do tecido conjuntivo de órgãos, como coração, vasos e articulações, além disso, pode gerar lesões cardíacas irreversíveis e sintomas como coreia, artralgia e lesões cutâneas (GOLDENZON et al. 2016).

Antes da confirmação diagnóstica, a artralgia foi solucionada com AINE, mas evoluiu com hipossaturação, taquipneia e dispneia, enquadrando-se como caso suspeito de infecção por COVID-19 de sintomas em grau moderado a grave. Devido ao cenário de pandemia, o paciente, com o uso de máscara cirúrgica, foi conduzido para isolamento respiratório. O quarto, como recomendado pelo Ministério da Saúde 
(BRASIL, 2020), foi mantido a portas fechadas, janelas abertas e sem uso de ar-condicionado. Como previsto em lei, o paciente menor de idade pode ter um acompanhante desde que orientado sobre a importância do distanciamento e rotina de higiene para prevenir contaminação.

O paciente foi medicado para broncospasmo com Prednisolona e Salbutamol Spray com uso de máscara e espaçador, como preconizado pelo Ministério da Saúde nos cuidados para evitar disseminação de COVID-19. Para Netto e Corrêa (2020), a infecção pelo novo coronavírus pode agravar com dispneia e sintomas torácicos correspondentes à pneumonia, associada à dessaturação de oxigênio, desvios de gases no sangue e alterações visíveis em radiografia torácica e outros exames de imagem. Assim, foi solicitado exame de imagem torácica.

A radiografia torácica (Figura 1) não evidenciou alterações pulmonares sugestivas de processo infeccioso, tendo como único achado a cardiomegalia. Ademais, considerando os sintomas do paciente, foram solicitados exames complementares de maior complexidade, como tomografia de tórax e ecocardiograma.

Figura 1 - Radiografia torácica de paciente.

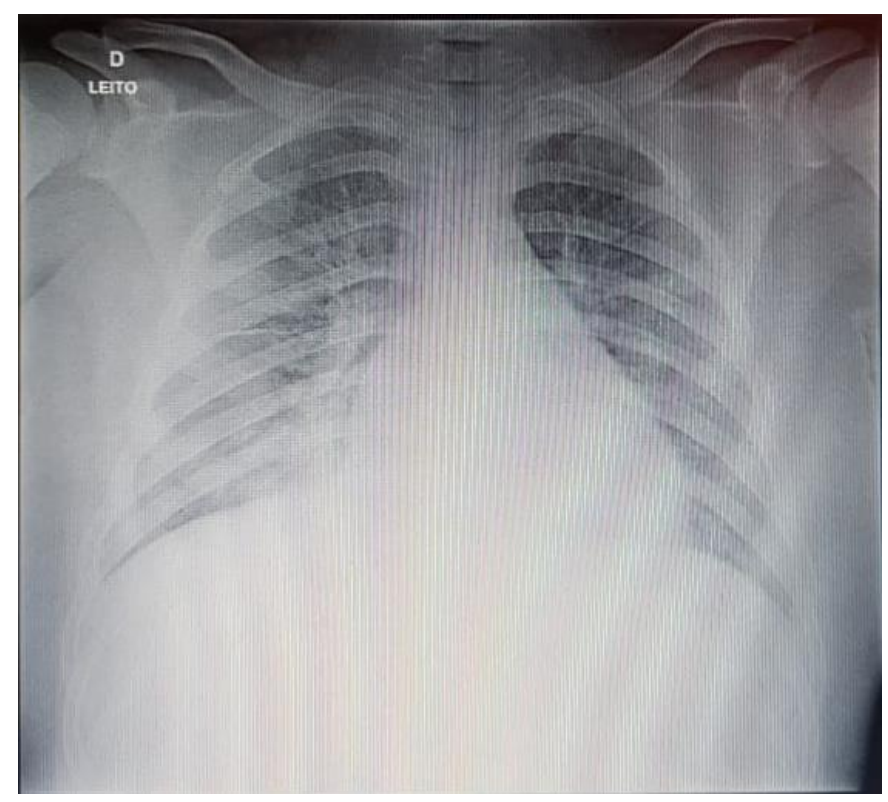

Fonte: os autores

A tomografia (Figura 2) evidenciou imagem pulmonar em "vidro fosco" e derrame pleural pequeno bilateral. Faria et al. (2020) refere que o aspecto mais comum nos achados tomográficos em pacientes com COVID-19 é a opacidade pulmonar em "vidro fosco", associada ou não a áreas de consolidação. Tal fato 
chamou atenção para o COVID-19 como diagnóstico diferencial do paciente, solicitando PCR de swab nasofaríngeo.

Figura 2 - Tomografia computadorizada de paciente.

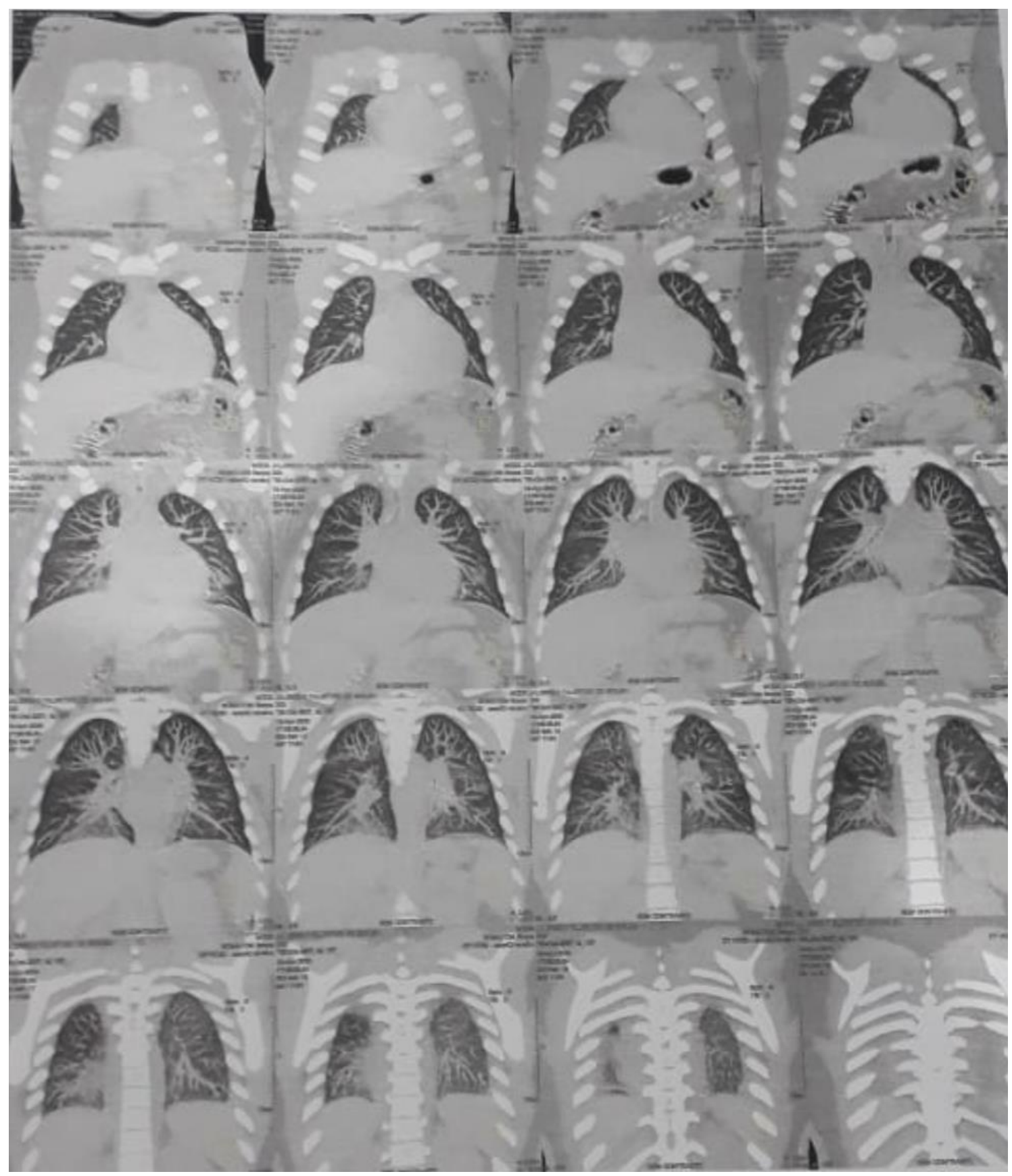

Fonte: os autores

O ecocardiograma evidenciou hipertrofia excêntrica de ventrículo esquerdo, insuficiência mitral acentuada, aparentemente por acometimento reumático, e insuficiência tricúspide de grau leve. 
Ainda sem o resultado do PCR para o novo coronavírus, além das alterações identificadas no ecocardiograma somadas aos sintomas respiratórios, aventou-se como diagnóstico diferencial uma possível complicação por COVID-19. Segundo Ronconi et al. (2020), a infecção pelo Sars-CoV-2 agrava a condição da doença de Kawasaki ou pode desencadear um processo inflamatório semelhante esta enfermidade, o qual possui sintomas como febre, conjuntivite, rash cutâneo, eritema faríngeo e adenomegalia. Entretanto, notou-se que o paciente não apresentava sintomas como febre persistente ou vasculites diversas, tendo em seu exame físico, apenas edema e dor em joelho esquerdo e lesões cicatriciais em membros inferiores bilateralmente, sem nenhum outro sinal ou sintoma que o enquadrasse nesta complicação.

Destarte, o resultado do PCR de swab nasofaríngeo para COVID-19 foi negativo, excluindo a hipótese de infeç̧ão pelo novo coronavírus associada a sintomas similares à doença de Kawasaki. Como o ecocardiograma evidenciou lesões valvares secundárias ao processo reumatológico, o paciente foi conduzido como provável quadro de febre reumática com acometimento cardiovascular e retirado do isolamento respiratório, iniciando tratamento adequado para erradicação do estreptococo beta-hemolítico do grupo A, já que não havia informação suficiente sobre faringoamigdalite antiga ou recente. Para tanto, foi prescrito ao paciente Amoxicilina com Clavulanato $500+125 \mathrm{mg}$ de 8/8 horas, conforme protocolo de atendimento da Instituição de saúde, ademais, ainda foi prescrito Furosemida 40 mg para alívio de sintomas respiratórios.

Exame neurológico do paciente sem alterações: pupilas isocóricas e fotorreagentes, sem déficits motores ou sensitivos, escala de coma de Glasgow 15, ausência de espasmos, tremores ou outros achados anormais que poderiam se associar à existência de Coreia de Sydenham, principal manifestação neurológica da febre reumática.

Com melhora do quadro, foi solicitada pesquisa de anticorpo antiestreptolisina $\mathrm{O}$ no organismo para confirmar infecção predisponente à febre reumatoide, a qual resultou em $410 \mathrm{Ui} / \mathrm{ml}(\mathrm{VR}<200 \mathrm{UI} / \mathrm{ml}$ ), confirmando, portanto, o diagnóstico de febre reumática segundo os critérios de Jones.

Por fim, o paciente recebeu alta para tratamento domiciliar com Furosemida $40 \mathrm{mg} 1$ comprimido pela manhã e Amoxicilina com Clavulanato $500+125 \mathrm{mg}$ de 8/8 horas, além disso, foi encaminhado ao ambulatório de cardiologia para acompanhamento de alterações cardíacas evidenciadas.

\section{REFERÊNCIAS}

BRASIL, Ministério da Saúde. Secretaria de Atenção Especializada à Saúde. Departamento de Atenção Hospitalar, Domiciliar e de Urgência. "Protocolo de Manejo Clínico da Covid-19 na Atenção Especializada", Brasília - DF, 2020.

NETTO, Raimundo; CORRÊA, José. Epidemiologia do surto de doença por coronavírus (COVID-19). Revista Desafios, Vol. 7. Manaus, Brasil. Disponível em: 
https://sistemas.uft.edu.br/periodicos/index.php/desafios/article/view/8710/16715. Acesso em: 09 jun 2020.

GOLDENZON, A. V. et al. Febre reumática: revisão e discussão dos novos critérios diagnósticos. Revista de Pediatria SOPERJ. 2016. v.16, n. 3, p 30-35.

FARIAS, L.P. et al. O sinal do halo como apresentação tomográfica pulmonar na COVID-19. Einstein (São Paulo). 2020.

RONCONI G. et al. SARS-CoV-2, which induces COVID-19, causes kawasaki-like disease in children: role of pro-inflammatory and anti-inflammatory cytokines. Journal of biological regulators and homeostatic agentes. 2020. V. 34, n. 3. 